\title{
Evaluation of shelf life of isotonic beverage enriched with cajuína
}

\author{
Luanne Morais Vieira GALVÃO ${ }^{1 *}\left(\mathbb{D}\right.$, Mariana de Morais SOUSA² $^{2}$ Afra Maria do Carmo Bandeira NASCIMENTO², \\ Bárbara Verônica Cardoso de SOUZA ${ }^{1}$, Lívio César Cunha NUNES ${ }^{1}$
}

\begin{abstract}
The segment of isotonic beverages has been expanding its market, introducing new flavors and meeting the growing demand for new products. Cajuína, a drink for which Piaui holds a geographical indication certificate, was used in the development of a new sports drink. This work aimed to evaluate the shelf life of isotonic cajuína beverages conditioned at room temperature and under refrigeration, by analyzing the physicochemical, sensorial, and microbiological parameters. The analyzed samples had stable pH $(<3.0)$, titratable total acidity $(0.18 \mathrm{~g} / 100 \mathrm{~mL})$, and ${ }^{\circ} \mathrm{Brix}\left(6.1^{\circ}\right.$ Brix $)$, and presented an acceptable soluble solids total/total titratable acidity (SST/ATT) ratio during storage. There was a vitamin C reduction of $83.3 \%$ and $75.27 \%$ from the initial amount in the beverage samples stored at room temperature and under refrigeration, respectively. Sensory analysis using the 9-point hedonic scale indicated good acceptance of the sports drink, and good buying intention. The sports drink also demonstrated high microbiological quality, with the absence of total coliforms, E. coli, molds, yeasts and Salmonella sp. The data from the stability study indicated that the isotonic cajuína drink retains its quality and safety, and can thus be consumed, for up to 150 days of storage.
\end{abstract}

Keywords: sports drinks; sensory analysis; stocking.

Practical Application: Cajuína isotonic drink was developed for use by athletes who want to make their life more 'natural'. The beverage is presented as a sports drink alternative without the addition of dyes, with regional flavor, and with a lower amount of added sugars.

\section{Introduction}

Adequate hydration practice before, during, and after exercise is essential for good physical performance in training and competitions, as well as for proper body warm-up and maintenance of health. The best hydration strategy during sports is the combination of water, carbohydrates, and electrolytes. It is important to observe the volume, frequency of intake, temperature and type of substrate used (Geraldini et al., 2017).

The American College of Sports Medicine (ACSM) and the Brazilian Society of Exercise and Sports Medicine (SBME) recommend the individualization of hydration strategies, considering the percentage of dehydration during the sporting event according to the intensity and duration of the exercise, sports modality, and the individual (Thomas et al., 2016; Sociedade Brasileira Medicina Esporte, 2009).

Isotonic beverages, also referred to as hydroelectrolytic beverages or sports drinks, are commonly consumed by adolescents and young adults. They have mineral concentrations similar to those found in organic fluids, and the balance between electrolytes (minerals) prevents dehydration during sports. Such beverages are typically carbonated, and have high acidity, and low carbohydrate content, ranging from 6 to $8 \%$.
The consumption of isotonic beverages during sports is often greater than that of water because of its palatability, characterized by the beverage temperature, sweetness, taste, taste intensity in the mouth and acidity (Pires et al., 2015).

In association with this worldwide trend, the segment of isotonic drinks has been expanding its market, introducing new flavors and meeting the growing demand for new products. From the consumer point of view, its rapid expansion is related to a healthy lifestyle and the consumption of products that go beyond just quenching thirst (De Marchi et al., 2003).

Cajuína is a typical Northeastern Brazilian beverage that has a Geographical Indication (GI) certificate from the State of Piauí and is registered as a Brazilian Cultural Heritage by the Institute of National Historic and Artistic Heritage (IPHAN) (Instituto Nacional da Propriedade Industrial, 2015).

The beverage is obtained from the clarification of cashew juice, without the addition of alcohol or sugar, and is rich in minerals and vitamin C. It has a yellow-amber coloration, due to the caramelization of sugars in cashew juice during the baking process (Silva et al., 2009). These are interesting characteristics, which give cajuína a vast market potential, including its use as a 
good alternative ingredient in the formulation of sports drinks. Thus, the objective of this work was to study the shelf life of isotonic cajuína beverages conditioned at room temperature and under refrigeration, by analyzing the physicochemical, sensorial and microbiological parameters.

\section{Materials and methods}

The processing and analysis of the isotonic cajuína beverage were carried out at the Laboratory of Technological Innovation and Entrepreneurship (LITE), of the Federal University of Piauí and at the Food Laboratory of the Federal Institute of Piauí, Campus Teresina Zona Sul.

\subsection{Materials}

The cajuína used in the processing of isotonic beverages was obtained from a small agroindustry, located in the municipality of Coivaras, Piauí, Brazil, from the 2016-2017 harvest. The samples were stored at room temperature until processing time. In addition to cajuína, the following were used to produce the sports drink: distilled water (Food Laboratory - IFPI), sucrose, sodium chloride, sodium citrate, potassium sorbate, potassium phosphate, citric acid and ascorbic acid (Dynamic Chemical Contemporary ${ }^{\circ}$ ). All ingredients and chemicals were food grade.

\subsection{Methods}

\section{Isotonic cajuína drink processing}

The preweighed ingredients were homogenized, and the beverage was then pasteurized in an open tank at $85^{\circ} \mathrm{C}$ for 5 seconds. After pasteurization, the beverage was cooled to $30^{\circ} \mathrm{C}$ and filled into previously sanitized $500 \mathrm{~mL}$ PET bottles. The drinks were divided into two batches, which were stored at room temperature $\left(25-30^{\circ} \mathrm{C}\right)$ and under refrigeration $\left(10-15^{\circ} \mathrm{C}\right)$.

\section{Physicochemical analysis}

The $\mathrm{pH}$ was determined using a $\mathrm{pH}$ meter, calibrated periodically with $\mathrm{pH} 4$ and 7 buffer solutions. The titratable total acidity was determined by titration with $0.1 \mathrm{M} \mathrm{NaOH}$ and the results expressed as \% citric acid. The total soluble solids ( $\left.{ }^{\circ} \mathrm{Brix}\right)$ were determined by refractometry, preferably at $20{ }^{\circ} \mathrm{C}$. The ratio of total soluble solids ( ${ }^{\circ}$ Brix)/total titratable acidity was subsequently calculated. The ascorbic acid content was determined by a titration method based on the reduction of 2,6-dichlorophenolindofenol indicator by ascorbic acid, as described by Instituto Adolfo Lutz (2008).

\section{Microbiological analysis}

The microbiological characterization was based on the quantification of molds and yeasts (colony-forming unit $/ \mathrm{mL}$, $\mathrm{CFU} / \mathrm{mL}$ ), coliforms, Escherichia coli, and verification of the presence of Salmonella sp., in accordance with the recommendations of Resolution ANVISA RDC n.12/2001 (Brasil, 2001). For all microbiological analyses, $3 \mathrm{M}^{\mathrm{TM}}$ Petrifilm ${ }^{\mathrm{TM}}$ plates were used. Microbiological analyses were performed according to the methodology described in the "Compendium of Methods for the Microbiological Examination of Foods, 4th Edition - APHA" (American Public Health Association, 2001).

\section{Acceptance sensory test}

The sensorial evaluations of the isotonic cajuína beverage were performed at the Sensory Analysis Laboratory, Federal Institute of Piauí (IFPI). The isotonic cajuína beverage formulations were analyzed by 180 untrained voluntary judges, divided into three study periods (at 30, 90, and 150 days of storage). The Free and Informed Consent Term, approved by the Research Ethics Committee (CEP) of the Federal University of Piauí on October 92017 (CAAE 58313216.0.0000.5214), was delivered to each volunteer to inform them about the purpose of the research, the composition of the product and the contacts of the researchers, in accordance with the recommendations of Resolution 196/96.

The beverages were served to the judges at an average temperature of $\pm 4^{\circ} \mathrm{C}$ in disposable cups containing $30 \mathrm{~mL}$ of the drink. Untrained judges evaluated the product with regards to the attributes of color, aroma, and flavor, using the structured 9-point hedonic scale, with the terms: "I liked very much" and "disliked very much". The purchase intent was similarly assessed using the terms "would certainly buy" and "certainly would not buy" (Dutcosky, 2013). The Acceptability Index (IA) of the beverage was also evaluated the following Equation 1:

$I A(\%)=100 \cdot A / B$

where: A - Average mark obtained by the product; B - Maximum mark given to the product.

\subsection{Statistical analysis}

The data thus obtained was tabulated and processed using Microsoft Excel software. The results were analyzed by analysis of variance (ANOVA) followed by the Tuckey tests using GraphPad Prism (version 6.0), considering $\mathrm{p}<0.05$ with a confidence level of $95 \%$.

\section{Results and discussion}

A stability study was performed to verify the shelf life prediction of the isotonic cajuína drink. Shelf life is the time period during which food remains safe for consumption while maintaining the desired sensory, physical, chemical and functional characteristics, and complies with the nutritional characteristics shown on the labeling under the recommended storage conditions. In other words, during the shelf life food has to meet two essential conditions: safety and quality (Giménez et al., 2012).

\subsection{Physicochemical stability evaluation}

The physicochemical parameters $(\mathrm{pH}$, titratable total acidity, total soluble solids, SST/ATT, and vitamin C content) of the isotonic cajuína beverage stored under different storage conditions were determined and the resulting values are presented in Table 1 .

Analysis of the $\mathrm{pH}$ values of isotonic cajuína beverages stored at room temperature (TA) and under refrigeration (TR) 
Table 1. Means and standard deviations of the physicochemical parameters of isotonic cajuína beverages stored at room temperature (TA) and under refrigeration (TR) after 0, 30, 60, 90, 120 and 150 days of storage.

\begin{tabular}{|c|c|c|c|c|c|c|c|c|c|c|}
\hline $\begin{array}{c}\text { Analysis/ } \\
\text { Period (days) }\end{array}$ & \multicolumn{2}{|c|}{$\mathrm{pH}$} & \multicolumn{2}{|c|}{$\begin{array}{l}\text { Titratable total acidity } \\
(\mathrm{g} / 100 \mathrm{~mL})\end{array}$} & \multicolumn{2}{|c|}{$\begin{array}{c}\text { Total soluble solids } \\
\text { ( }{ }^{\circ} \text { Brix) }\end{array}$} & \multicolumn{2}{|c|}{ Ratio ( ${ }^{\circ}$ Brix/Acidity) } & \multicolumn{2}{|c|}{$\begin{array}{l}\text { Vitamin C content } \\
(\mathrm{mg} / 100 \mathrm{~mL})\end{array}$} \\
\hline 0 & $3.58 \pm 0.03^{\mathrm{aA}}$ & $3.66 \pm 0.07^{\mathrm{aA}}$ & $0.19 \pm 0.0^{\mathrm{aA}}$ & $0.18 \pm 0.01^{\mathrm{aA}}$ & $6.1 \pm 0.0^{\mathrm{aA}}$ & $6.1 \pm 0.0^{\mathrm{aA}}$ & $32.85 \pm 0.60^{\mathrm{aA}}$ & $33.96 \pm 1.32^{\mathrm{aA}}$ & $42.33 \pm 4.58^{\mathrm{aA}}$ & $46.97 \pm 1.39^{\mathrm{aA}}$ \\
\hline 60 & $3.27 \pm 0.03^{\mathrm{cA}}$ & $3.22 \pm 0.02^{\mathrm{cA}}$ & $0.18 \pm 0.0^{\mathrm{aA}}$ & $0.18 \pm 0.01^{\mathrm{aA}}$ & $6.1 \pm 0.0^{\mathrm{aA}}$ & $6.1 \pm 0.0^{\mathrm{aA}}$ & $33.56 \pm 0.66^{\mathrm{aA}}$ & $33.18 \pm 0.0^{\mathrm{aA}}$ & $21.16 \pm 4.58^{\mathrm{bA}}$ & $23.81 \pm 7.94^{\mathrm{bcA}}$ \\
\hline 90 & $3.22 \pm 0.01^{\mathrm{cA}}$ & $3.12 \pm 0.01^{\mathrm{cdA}}$ & $0.18 \pm 0.03^{\mathrm{aA}}$ & $0.18 \pm 0.0^{\mathrm{aA}}$ & $6.1 \pm 0.0^{\mathrm{aA}}$ & $6.1 \pm 0.0^{\mathrm{aA}}$ & $34.13 \pm 0.67^{\mathrm{aA}}$ & $34.13 \pm 0.67^{\mathrm{a}}$ & $20.25 \pm 2.69^{\mathrm{bA}}$ & $21.81 \pm 2.7^{\mathrm{cA}}$ \\
\hline
\end{tabular}

Means followed by the same lowercase letter between columns and uppercase between lines do not differ significantly from each other, at $5 \%$ probability, by the Tuckey test.

after a 150-day period shows a significant difference betwbeen the samples $(\mathrm{p}<0.05)$. In the TA sample, the $\mathrm{pH}$ values ranged from $3.58 \pm 0.03$ to $2.0 \pm 0.02$, and the $\mathrm{pH}$ of the TR sample ranged from $3.66 \pm 0.07$ to $2.88 \pm 0.05$. When we compared the $\mathrm{pH}$ values between samples, in the same period, it was verified that no significant difference exists $(\mathrm{p}<0.05)$, by the Tuckey test (Table 1).

The $\mathrm{pH}$ is determined as a parameter of quality. According to Dionisio et al. (2018), foods are classified as low acidity $(\mathrm{pH}>4.5)$, acidic ( $\mathrm{pH} 4.0-4.5)$, and very acidic $(\mathrm{pH}<4.0)$. This classification is based on the minimum $\mathrm{pH}$ for the multiplication and production of Clostridium botulinum toxin $(\mathrm{pH}=4.5)$, and the minimum $\mathrm{pH}$ for the multiplication of the great majority of bacteria $(\mathrm{pH}=4.0)$. The elaborated isotonic drink classifies as "very acidic", which favors its microbiological stability and, consequently, its consumption safety. By the analysis of variance, it was verified that the titratable total acidity (ATT) of the isotonic cajuína beverage samples showed no significant statistical difference at $5 \%$ probability. From Table 1, it can be observed that the titratable total acid values in the sample stored at room temperature (TA) ranged from 0.19 to $0.18 \mathrm{~g} / 100 \mathrm{~mL}$, and when conditioned under refrigeration (RT), the acidity of the beverage remained $0.18 \mathrm{~g} / 100 \mathrm{~g}$ during the study period.

The stability of the $\mathrm{pH}$ and titratable total acidity values indicated that the organic acids present in the sports drink did not undergo oxidation during storage (Lima et al., 2008). During the 150 days of storage, the beverages presented total soluble solids values of $6.1^{\circ} \mathrm{Brix}$, and there was no significant difference between $(p<0.05)$ by the Tuckey test (Table 1$)$. The preservation of total soluble solids values during the storage period was also verified by De Marchi et al. (2003), in which they studied the shelf life of a natural isotonic of passion fruit packed in carton packs, stored at room temperature and under refrigeration $\left(8.2^{\circ} \mathrm{Brix}\right)$. Additionally, in a study by Petrus \& Faria (2005), the total soluble solids content of 3 batches of isotonic beverage, conditioned in a plastic bottle at $25{ }^{\circ} \mathrm{C}$, remained constant during a storage period of 26 weeks.

Research such as that conducted by Bovi et al. (2017), which produced an isotonic drink with buriti oil nanoemulsions, demonstrated that after 38 days of storage there were changes in the averages of the physicochemical analyses. The $\mathrm{pH}$ values decreased from $2.92 \pm 0.01$ to $2.72 \pm 0.05$ ), presenting a significant difference $(\mathrm{p}<0.05)$ by the Tuckey test. The mean values of ${ }^{\circ}$ Brix $(4.9 \pm 0.06$ to $5.13 \pm 0.12)$ and total titratable acidity $(0.173 \pm 0.001$ to $0.177 \pm 0.004)$ were not significantly different during the study time.

The coefficient measured for our cajuína sports drinks did not differ statistically $(\mathrm{p}<0.05)$ at different storage temperatures and during the 150 days of the study. The values found ranged from $32.85 \pm 0.60$ to $34.70 \pm 0.68$ (Table 1). The small variation between the total acidity values of the isotonic drink contributed to a lower coefficient of variation for the ratio, indicating that the beverage has a desirable degree of sweetness, directly affecting the sensory evaluation of the products.

The values obtained for the vitamin $\mathrm{C}$ content showed a significant difference $(p<0.05)$ between the two beverage samples under different storage conditions (TA and TR). However, the comparison of the mean vitamin $C$ values among samples stored at different temperatures showed no significant difference during the 150 days of storage (Table 1).

The isotonic cajuína liquor stored at room temperature (TA) had a vitamin $\mathrm{C}$ reduction of $83.3 \%$, compared to the initial amount of $42.33 \mathrm{mg} / 100 \mathrm{~mL}$. According to Özkan et al. (2004), the depletion of ascorbic acid may be due to factors such as: storage temperature $\left(28 \pm 2^{\circ} \mathrm{C}\right.$ ); exposure to light (depending on whether bottles are PET or transparent); oxidation reactions due to the oxygen present inside the package, as well as the oxygen dissolved in the drink; and the possible occurrence of reactions involving ascorbic acid (for example, the Maillard Reaction).

If the quality index considered in the shelf life determination of the product is taken as the degradation of vitamin $\mathrm{C}$, the shelf life can be determined as the time required to reach $50 \%$ reduction in relation to the initial value, according to Faria (1990). In this way, the shelf life of the isotonic cajuína beverage would be 60 days (Table 1). However, since an isotonic drink is not primarily intended to act as a source of vitamin $\mathrm{C}$, but rather as a hydroelectrolyte repository, this reduction is not a critical or limiting factor in the shelf life of the product. The results of our study corroborate those of other studies, such as that of Castro et al. (2006), which evaluated the content and stability of vitamin C of commercially available isotonic drinks, totaling 14 samples from 3 different manufacturers. For all manufacturers, regardless of the type of packaging or shelf life, the value found was higher than stated, which may be due to overdosing, to compensate for losses during processing. It was also found that there was a 
loss of vitamin $\mathrm{C}$ by the end of the six-month shelf life, on the order of 5 and $30 \%$ for the two brands evaluated, respectively.

\subsection{Evaluation of microbiological stability}

The results of the microbiological stability study of isotonic cajuína beverage, stored at room temperature (TA) and under refrigeration temperature (TR), after periods of $0,30,60,90$, 120 and 150 days are shown in Table 2.

For isotonic cajuína beverage stored at different temperatures, the results showed the absence of total coliforms, E coli. and Salmonella sp. during the study period.

The counts of molds and yeasts in most of the lots/study periods were zero. However, the isotonic drink sample TA after 90 days storage and the isotonic samples TA and TR after 120 days storage exhibited $1 \mathrm{UFC} / \mathrm{g}$ of molds and yeasts (Table 2).

The current legislation, RDC no 12 of January 2 2001, does not establish a standard for the amount of microorganisms allowed in isotonic beverages. When comparing isotonic cajuína beverage with beverages such as juices, soft drinks, soft drinks and other non-alcoholic beverages, excluding dairy and chocolate (cocoa and similar) beverages where no values were established for molds and yeasts, the results of the beverage evaluated in this work can be considered microbiologically safe.

The low microbial counts of beverages in this study can be attributed to the effectiveness of the packaging asepsis process and the good handling practices during the processing of the isotonic cajuína beverage, which were employed to reduce the microbial load of this beverage. The microbial development in the beverage was also controlled through the use of high temperatures (pasteurization), and chemical agents, such as potassium benzoate and potassium phosphate, which act as a mold and yeast inhibitors and also inhibit the growth of some bacteria. Moreover, the use of organic acids like citric acid, which lowers the $\mathrm{pH}$ of the beverage, inhibits the growth of some microorganisms.

In this work, microbiological evaluations do not determine the shelf life of the isotonic cajuína beverage. This may be longer than 150 days as the initial characteristics were maintained during the storage period, in both the beverage stored at room temperature and that stored under refrigeration.
Petrus \& Faria (2005) developed an isotonic drink in a microbiologically stable plastic bottle, dispensing with refrigeration. They compared 3 lots: lot $1-10.0 \mathrm{mg} / \mathrm{L}$ sorbate, lot $2-50 \mathrm{mg} / \mathrm{L}$ sorbate and lot 3 - control (no preservative). Microbiological analyses (counts of aerobic mesophilic microorganisms, molds and yeasts) showed that the isotonic drink that had been pasteurized and conditioned in plastic bottles showed stability in all three batches produced, indicating the possibility of eliminating the chemical preservative from the product. De Marchi et al. (2003) studied the shelf life of a natural isotonic of passion fruit packed in carton packs, stored at room temperature and under refrigeration. They observed that there was no variation for the counts of molds and yeasts and for the counts of total mesophilic aerobic microorganisms, for the two types of beverage. They observed that the microorganism count was low and that the beverage remained practically unchanged during the whole storage period.

\subsection{Evaluation of sensory stability}

Sensory analyses of cajuína isotonic beverages stored at room temperature (TA) and refrigeration temperature (TR) were performed after storage periods of 30,90 and 150 days. For each period, acceptability tests were performed with 60 untrained testers (sensory assessors), who showed interest and willingness to judge. The majority of the participants were women: $59 \%, 69 \%$ and $62 \%$, in the study periods at 30,90 and 150 days, respectively. The mean age of the testers was $25.2 \pm 10.78$ years, $23.5 \pm 10.33$ years and $26.7 \pm 12.10$ years for the study periods at 30,90 and 150 days, respectively.

The tasters of the sensory analysis were asked the following questions: "Do you practice physical activity?", "Do you consume cajuína?" and "Do you consume isotonic drinks?". Most of the testers who participated in the sensory acceptability test $(57.1 \%$, $54 \%, 46.7 \%$ ) for the study periods at 30, 90 and 150 days, respectively, answered that "they rarely practice physical activity". When asked about cajuína consumption, more than $84 \%$, in all periods of the study, answered "yes."

The frequencies of consumption of some type of isotonic drink (sports drink) were as follows: $47.6 \%$ and $41.3 \%$ of the tasters "rarely consumed" isotonic drink in the 30 and 90 day study periods, respectively, and $36.7 \%$ "never consumed" any type of isotonic drink, within the 150 day study period.

Table 2. Microbiological analyses of cajuína isotonic beverage stored at room temperature (TA) and under refrigeration (TR) after storage periods of $0,30,60,90,120$ and 150 days.

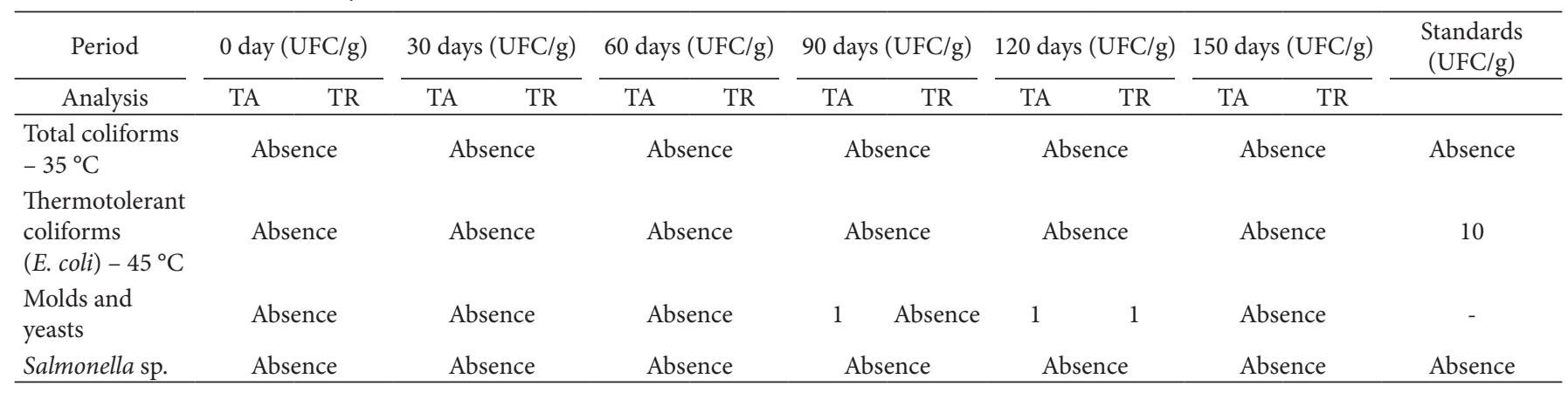


Table 3. Sensory analysis of the acceptability of isotonic cajuína beverage stored at room temperature (TA) and under refrigeration (TR) after storage periods of 30,90 and 150 days.

\begin{tabular}{|c|c|c|c|c|c|c|c|c|}
\hline$\frac{\text { Attributes }}{\text { Time (days) }}$ & \multicolumn{2}{|c|}{ Color (score: 1-9 point) } & \multicolumn{2}{|c|}{ Flavor (score: 1-9 point) } & \multicolumn{2}{|c|}{ Taste (score: 1-9 point) } & \multicolumn{2}{|c|}{$\begin{array}{l}\text { Purchase intention } \\
\text { (score: } 1-5 \text { point) }\end{array}$} \\
\hline 30 & $7.4 \pm 1.09^{\mathrm{aA}}$ & $6.4 \pm 1.61^{\mathrm{bB}}$ & $7.9 \pm 1.25^{\mathrm{aA}}$ & $7.3 \pm 1.36^{\mathrm{bA}}$ & $7.9 \pm 1.12^{\mathrm{aA}}$ & $6.7 \pm 1.74^{\mathrm{bB}}$ & $4.1 \pm 0.82^{\mathrm{aA}}$ & $3.3 \pm 1.09^{\mathrm{bA}}$ \\
\hline 150 & $7.4 \pm 1.56^{\mathrm{aA}}$ & $6.1 \pm 2.09^{\mathrm{bB}}$ & $7.8 \pm 1.17^{\mathrm{aA}}$ & $7.0 \pm 1.77^{\mathrm{bB}}$ & $7.1 \pm 2.12^{\mathrm{aA}}$ & $6.4 \pm 2.36^{\mathrm{bA}}$ & $4.0 \pm 1.14^{\mathrm{aA}}$ & $3.5 \pm 1.20^{\mathrm{bA}}$ \\
\hline
\end{tabular}

Values express mean \pm standard deviation $(n=60)$. Values followed by the same lowercase letter between columns and uppercase between rows do not differ significantly from each other $(\mathrm{p}<0.05)$ by the Tuckey test.

Table 4. Acceptability index (IA) for isotonic cajuína beverage stored at room temperature and under refrigeration.

\begin{tabular}{|c|c|c|c|c|c|c|c|c|}
\hline Attributes & \multicolumn{2}{|c|}{ Color IA (\%) } & \multicolumn{2}{|c|}{ Flavor IA (\%) } & \multicolumn{2}{|c|}{ Taste IA (\%) } & \multicolumn{2}{|c|}{ Purchase intention IA (\% } \\
\hline Time (days) & TA & TR & TA & TR & TA & TR & TA & T.R \\
\hline 30 & 80.95 & 70.37 & 86.77 & 79.72 & 85.36 & 71.43 & 80.0 & 64.44 \\
\hline 90 & 81.6 & 72.92 & 82.12 & 82.99 & 79.34 & 75.17 & 72.81 & 70.0 \\
\hline 150 & 82.22 & 67.59 & 86.85 & 78.15 & 78.7 & 70.56 & 79.67 & 69.33 \\
\hline
\end{tabular}

A sensorial test was performed to verify the response of the consumers in relation to the storage of the isotonic cajuína drink. The averages of the acceptability scores (color, aroma, and flavor) and the purchase intention are shown in Table 3.

Analysis of the data obtained regarding color, flavor, taste and purchase intention, shows that there was no significant difference $(\mathrm{p}<0.05)$ between the isotonic beverage samples $\mathrm{TA}$ and TR, during the stages in which the sensory tests were performed (Table 3). The highest averages obtained in the sensory tests were for taste and flavor attributes with an average value of 7.9 for the beverage stored at room temperature (time 30 days), which is equivalent to the "regularly enjoyed" hedonic scale.

The results showed that there was no change in the attribute notes during the 150 days of storage, at room temperature or under refrigeration, of the isotonic cajuína drink. Thus, it can be stated that the storage temperature did not interfere with the sensorial characteristics. The isotonic beverage stored at room temperature (TA) obtained scores above 7.0, which correspond to "I enjoyed regularly" in the hedonic scale (Table 3) in all attributes (color, aroma and flavor) and study times.

Regarding the color of the TR beverage, the means obtained during the sensorial analysis period were between 6.1 and 6.6, corresponding to "slightly liked" (Table 3). Visually, the color difference between the studied samples was noticeable: the TA drink was darker than the TR drink, making it less attractive for the tasters.

According to Damodaran et al. (2010), the tendency for darkening of the beverage is probably due to non-enzymatic processes, such as the Maillard reaction. Under certain storage conditions, the reducing sugars of foods produce brown pigments that may be desirable or undesirable. The chemical reaction occurs mainly between $\mathrm{D}$-glucose (reducing sugar) and a primary amine group (a free amino acid or amino acid side chain of a protein molecule).

The color is an important quality factor in the choice of a food product, which is the reason underlying the high demand for dyes by the food industry (Estupiñan et al., 2011). Currently, industry and customer preferences are to use natural dyes in the formulation of new products. For this reason, our work has used cajuína as the only color-imparting ingredient in the preparation of the isotonic, and the use of artificial colors, which is usual in the sports drinks industry, was avoided.

A statistically significant difference $(\mathrm{p}<0.05)$ was found between the TA and TR cajuína isotonic beverage samples, by the Tuckey test, for the following attributes: the color (time 30 and 150 days); the flavor (time 150 days and time 30 days) (Table 3). These results indicated that, despite the formulation of the beverage being the same, the samples were not equally acceptable when stored at different temperatures.

Table 4 shows the acceptability indexes (IA), which are calculated from the scores obtained in the acceptability test. The beverage stored at room temperature had all acceptability indexes (IA) higher than $70 \%$, and the aroma attribute in the 90 -day period, presented the highest acceptability index (86.85\%). The lowest acceptability index (AI) was attributed to the color of the beverage stored under refrigeration at 150 days, with a value of $67.69 \%$.

According to several studies, for a product to be considered acceptable in terms of sensory properties by the tasters, it is necessary for it to obtain an Acceptability Index of at least 70\% (Teixeira et al., 1987). Thus, the sample of isotonic cajuína beverage stored at room temperature was well accepted and commercially viable.

\section{Conclusions}

The data from the stability study indicated that isotonic cajuína drink retains a high level of quality and safety, and is thus fit for consumption, after up to 150 days of storage. The beverage was stable microbiologically and sensorially, and slight physical and chemical changes in its composition did not spoil the product stored at room temperature and under refrigeration.

With these characteristics, the cajuína-based isotonic beverage has been shown as an alternative to sports drinks, without the addition of dyes, with regional flavor, and with a lower amount of added sugar. It is thus being directed to athletes who want to make their life even more natural. 


\section{References}

American Public Health Association - APHA, Committee on Microbiological for Foods. (2001). Compendium of methods for the microbiological examination of foods (4th ed.). Washington: APHA.

Bovi, G. G., Petrus, R. R., \& Pinho, S. C. (2017). Feasibility of incorporating buriti (Mauritia flexuosa L.) oil nanoemulsions in isotonic sports drink. International Journal of Food Science \& Technology, 52(10), 2201-2209. http://dx.doi.org/10.1111/ijfs.13499.

Brasil, Agência Nacional de Vigilância Sanitária - Anvisa. (2001, January 10). Aprova o Regulamento Técnico sobre padrões microbiológicos para alimentos (Resolução RDC n ${ }^{\circ} 12$, de 2 de janeiro de 2001). Diário Oficial [da] República Federativa do Brasil.

Castro, F. J., Scherer, R., \& Godoy, H. T. (2006). Evaluation of the content and stability of B vitamins and vitamin $\mathrm{C}$ in isotonic and energy drinks. Nature Chemistry, 29(4), 719-723.

Damodaran, S., Parkin, K. L., \& Fennema, O. R. (2010). Food chemistry of phenenma (4. ed.). Porto Alegre: Artemed.

De Marchi, R., Cardello, H. M. A. B., \& Monteiro, M. (2003). Avaliação da vida-de-prateleira de um isotônico de maracujá natural (Passiflora edulis $\mathrm{f}$. flavicarpa Deg.). Brazilian Journal of Food Technology, 6(2), 291-300.

Dionisio, A. P., Wurlitzer, N. J., Pinto, C. O., Goes, T. S., Borges, M. F., \& Araujo, I. M. S. (2018). Processamento e estabilidade de uma bebida de caju e yacon durante o armazenamento sob refrigeração. Brazilian Journal of Food Technology, 21, e2016189.

Dutcosky, S. D. (2013). Food sensory analysis (4. ed.). Curitiba: Champagnat.

Estupiñan, D. C., Schwartz, S. J., \& Garzón, G. A. (2011). Antioxidant activity, total phenolics content, anthocyanin, and color stability of isotonic model beverages colored with andes berry (Rubus glaucus Benth) anthocyanin powder. Journal of Food Science, 76(1), S26-S34. http://dx.doi.org/10.1111/j.1750-3841.2010.01935.x. PMid:21535712.

Faria, J. A. F. (1990). Stability of foods in plastic packaging. Campinas: UNICAMP/FEA.

Geraldini, S., Cruz, I. F., Romero, A., Fonseca, F. L. A., \& Campos, M. P. (2017). Isotonic sports drink promotes rehydration and decreases proteinuria following karate training. Brazilian Journal of Nephrology, 39(4), 362-369. http://dx.doi.org/10.5935/0101-2800.20170067. PMid:29319761.
Giménez, A., Ares, F., \& Ares, G. (2012). Sensory shelf-life estimation: a review of current methodological approaches. Food Research International Montevideu, 1(49), 311-325. http://dx.doi.org/10.1016/j. foodres.2012.07.008

Instituto Adolfo Lutz - IAL. (2008). Physical-chemical methods for food analysis (4. ed.). São Paulo: IAL.

Instituto Nacional da Propriedade Industrial - INPI. (2015). Cajuína do Piauí. Retrieved from: http://www.inpi.gov.br/noticias/cajuínado-piaui

Lima, A. S., Maia, G. A., Souza, P. H. M., Silva, F. V. G., \& Figueiredo, E. A. T. (2008). Development of mixed drink based on coconut water and acerola juice. Food Science and Technology, 28(3), 683-690. http://dx.doi.org/10.1590/S0101-20612008000300026.

Özkan, M., Aysegül, K., \& Cemeroğlu, B. (2004). Effects of hydrogen peroxide on the stability of ascorbic acid during storage in various fruit juices. Food Chemistry, 88(4), 591-597. http://dx.doi.org/10.1016/j. foodchem.2004.02.011.

Petrus, R. R., \& Faria, J. A. F. (2005). Processing and evaluation of isotonic drink stability in plastic bottle. Food Science and Technology, 25(3), 518-524. http://dx.doi.org/10.1590/S0101-20612005000300021.

Pires, E. G., Carneiro, F. G., Melo, J. B. C. A., Milanez, A. F., Mendes, A. D. L., \& Bonan, P. R. F. (2015). Influência do pH de bebidas isotônicas sobre a microdureza de resinas compostas. Arquivos em Odontologia, 51(3), 123-128.

Silva, R. M. No., Abreu, F. A. P., \& Paiva, F. F. A. (2009). Processing of the peduncle of cashew: cajuina. Fortaleza: Embrapa Tropical Agroindustry.

Sociedade Brasileira Medicina Esporte - SBME. (2009). Dietary modifications, water replenishment, food supplements and drugs: evidence of ergogenic action and potential health risks. British Journal of Sports Medicine, 15(3), 3-12.

Teixeira, E., Meinert, E. M., \& Barbetta, P. A. (1987). Análise sensorial de alimentos. Florianópolis: UFSC.

Thomas, D. T., Erdman, K. A., \& Burke, L. M. (2016). Nutrition and athletic performance. Medicine and Science in Sports and Exercise, 48(3), 543-568. http://dx.doi.org/10.1249/MSS.0000000000000852. PMid:26891166. 